\title{
Solid waste management practices and challenges in seven cities of Nepal before and during lockdown against COVID-19 pandemic
}

\author{
Bikash Adhikari ${ }^{1}$, Saroj Koirala ${ }^{2,3,{ }^{*},}$ Nitesh Khadka ${ }^{2,3}$, Nitesh Koirala ${ }^{1}$ \\ ${ }^{1}$ Department of Environment Science and Engineering, Kathmandu University, Nepal \\ ${ }^{2}$ Institute of Mountain Hazards and Environment, Chinese Academy of Sciences, Chengdu 610041, China \\ ${ }^{3}$ University of Chinese Academy of Sciences, Beijing 100049, China
}

(Received: 07 May 2021; Revised: 28 June 2021; Accepted: 29 June 2021)

\begin{abstract}
The nationwide lockdown imposed to control the spread of novel coronavirus induced dramatic alterations in different sectors of the Nepalese governance, including Solid Waste Management (SWM) practices. The study identifies SW collection gaps in seven major cities of Nepal and highlights the municipal and public households on SW management practices before and during the lockdown to emphasize the linkage between COVID-19 and SWM. It includes information on solid waste status, collection frequency and coverage, workers' safety practices, types of vehicles operated for collection and alternative methods adopted by households to manage SW during the lockdown. For this, 1329 households survey and key informant interviews were conducted in seven cities of Nepal during the lockdown. It was found that although the coverage of the collection service was similar during the pandemic in surveyed households, there was a drastic decrease in the collection frequency leading to a collection gap of around 570 tons/day. More than $50 \%$ of the surveyed households adopted no proper alternative measures as they claimed that they stored solid waste with proper management so that municipal authorities can take it. While other $50 \%$ adopted practices such as open burning, throwing in streets or composting. The study reveals poor occupational health and safety practices among solid waste workers due to the unavailability of safety gear and equipment despite being aware of the modes of transmission of the virus. The pandemic exacerbated the challenges of smooth SWM as it is an essential and needy service. This study highlights the need for a timely strategic management framework to be developed by the government to continue the smooth SWM practices during the lockdown.
\end{abstract}

Keywords: COVID-19, emergency plans, lockdown, waste collection, waste generation

\section{Introduction}

Solid waste management (SWM) has become one of the primary issues, especially in developing countries, due to the rapid and unmanaged urbanization (Ferronato \& Torretta, 2019). The waste problem, due to the growing global population, consumerism and the linear approach to industrialization, has become an increasingly severe issue in the $21^{\text {st }}$ century (D'Amato et al., 2016; De Feo et al., 2019; Minelgaite \& Liobikiene, 2019; Stoeva \& Alrikson, 2017). Human activities create waste, and these wastes are handled, stored, collected and disposed of, which can pose risks to the environment and public health (Saxena et al., 2010; Zhu et al., 2008). In urban areas, especially in the rapidly urbanizing cities of the developing world, municipal solid waste management (MSWM) problems and issues are of immediate importance, and most governments have acknowledged the importance of MSWM. However, rapid population growth overwhelms the capacity of most municipal authorities to provide even the most basic services (Zhu et al., 2008). Municipal solid waste (MSW) is generally a combination of household and commercial refuse generated from the living community (Gupta et al., 2015). According to the World
Bank report (World Bank, 2012), it was estimated that 4.3 billion urban residents would generate $1.42 \mathrm{~kg} / \mathrm{capita} /$ day of municipal solid waste (2.2 billion per year) by 2025 . Moreover, South Asia Region (SAR) will have an urban waste generation of $0.77 \mathrm{~kg} /$ capita/day and 567,545 tons/day from the projected urban population of 734 million by 2025. Furthermore, the World Bank report has highlighted that the waste generation in developed countries is more than that in a developing country because of the standard of living (World Bank, 2012).

Increasing population levels, booming economy, rapid urbanization and the rise in community living standards have greatly accelerated the municipal solid waste generation rate in developing countries (Guerrero et al., 2013; Minghua et al., 2009). According to the new constitution of Nepal 2015, administrative Nepal is divided into 7 Provinces, 77 Districts and Municipalities, of which these municipalities are classified into the urban municipality and 460 rural municipalities. Furthermore, the urban municipality is classified into three categories with

\footnotetext{
* Corresponding author: sarojkoirala1@gmail.com
} 
their respective counts: 6 Metropolitan cities, 11 Sub metropolitan cities and 753 municipalities. Thus, in Nepal, increasing population and rapid urbanization are the leading cause of municipal solid waste generation (Pokhrel \& Viraraghavan, 2005).

Coronavirus Disease 2019 (COVID-19) is a respiratory disease caused by the virus named SARS-CoV-2 (Mol \& Caldas, 2020). The first case of COVID-19 was identified in Wuhan, China, on 31 ${ }^{\text {st }}$ December 2019 and has since spread globally, leading to an ongoing pandemic (Wu et al., 2020). The first official case of COVID-19 in Nepal was identified on 24th January 2020 (Pun et al., 2020). As a control measure against COVID-19, the Government of Nepal issued a nationwide lockdown from 24th March 2020 that ended on $21^{\text {st }}$ July 2020. A complete close-down was implemented during the lockdown by prohibiting domestic and international travels, except for essential services. However, the municipal waste collection service is regarded as an essential service, lockdown imposed during the COVID-19 pandemic affected Nepal's municipal waste collection process.

Problems in solid waste management arose amid the lockdown of COVID-19 in major populated cities of Nepal due to the decrement in collection frequency of MSW. Improper MSW management through open burning, open dumping and unsanitary landfilling contributes to many environmental problems, such as air pollution, human health hazards, and ecosystem damages (Laurent et al., 2014). Thus, this study aims to know the status, collection frequency and public reaction on unmanaged MSW before and during the lockdown against COVID-19.

\section{Materials and Methods \\ Study Area}

Nepal is a Himalayan country, located between $26^{\circ} 22^{\prime}$ to $30^{\circ} 27^{\prime} \mathrm{N}$ and $80^{\circ} 40^{\prime}$ to $88^{\circ} 12^{\prime} \mathrm{E}$ and the climate is influenced by the South Asian Monsoon system (Sharma et al., 2020). This study focused on the seven cities of Nepal, including the Capital city, Kathmandu Valley (Figure 1). Kathmandu Valley in our study includes only three municipalities, i.e., Kathmandu Metropolitan City, Lalitpur Metropolitan City and Bhaktapur Municipality. Thus, this study focused on nine municipalities that included four metropolises, four sub-metropolises, and one municipality (Figure 1). Five municipals, i.e., Itahari, Hetauda, Bharatpur, Butwal and Nepalgunj, lies in lowlands, whereas the remaining lies in the Hilly region of Nepal.

The populations of Kathmandu, Lalitpur, Pokhara and Bharatpur metropolitan cities are 1,442,300, 226,728, 264,991, and 199,867, respectively (CBS, 2012). Similarly, Itahari, Hetauda, Butwal, and Nepalgunj sub-metropolitan cities have 140,517; 152,875; 138,742, and 138,951, population respectively, and Bhaktapur municipality have a population of 304,651 individuals (CBS, 2012).

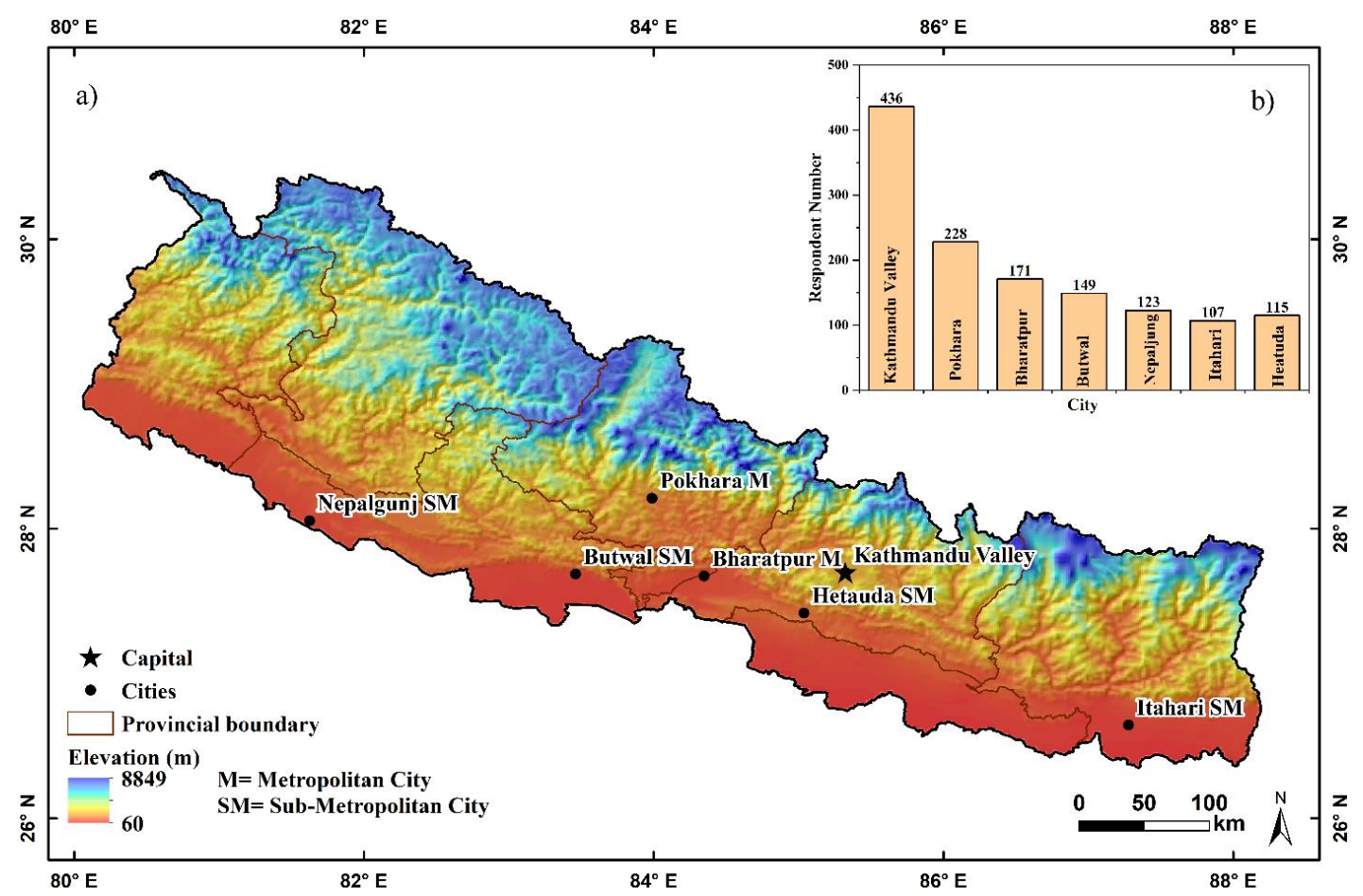

Figure 1 (a) Study area showing the seven cities of Nepal. Kathmandu Valley includes Kathmandu Metropolitan City, Lalitpur Metropolitan City and Bhaktapur Municipality in this study. (b) The inset shows the total number of respondents from each city. 


\section{Data and Methods}

A household questionnaire survey that included SW collection frequency, SW management techniques and SW collection medium in the seven most densely populated cities of Nepal were administered during the lockdown. The regular municipal waste collection data before (before $24^{\text {th }}$ March 2020) and during the imposition of lockdown (after 24th March 2020-21st July 2020) was collected from the respective municipalities' office. Additional municipal data was collected through questionnaires and key informant interviews (KII) with the municipal officers, environment officers and private organizations (8 KIIs). The public respondent data was monitored to comply with the municipal data. To ensure this, the data acquired from the municipality office was triangulated with the data from the field survey. The sources of data for this study are systematically presented in Figure 2.

A total of 1329 respondents (each from one house) participated in the questionnaire from seven densely populated cities of Nepal (Figure 1), which were selected using a purposive sampling technique. Among 1329 respondents, an average of five respondents was ensured from every ward of the municipality. The surveyed municipality and number of respondents during the survey is presented in Figure $1 \mathrm{~b}$. The data reveal that Kathmandu Valley covered the highest percentage of respondents with $32.8 \%$, followed by Pokhara Metropolitan City with coverage of $17.2 \%$. Similarly, the figures were followed by Bharatpur Metropolitan, Butwal Sub-Metropolitan city, Nepalgunj Sub-Metropolitan city, Hetauda SubMetropolitan city, Itahari Sub-metropolitan city with coverage of $12.9 \%, 11.2 \%, 9.3 \%, 8.7 \%$, and $8.1 \%$, respectively. These variations in the number of respondents of the individual places were due to surveyor circulation rate and willingness of people to participate in the survey.

The data obtained were analyzed in Statistical Package for the Social Sciences (SPSS) V. 27 software developed by IBM. A codebook was prepared in SPSS where selected cities, types of vehicles used for SW collection, frequency of collection and its management types are assigned a particular code. These codes are numeric and represent the respective variable they are assigned. Descriptive statistical analysis was used to demonstrate a gap in waste collection frequency during the lockdown.

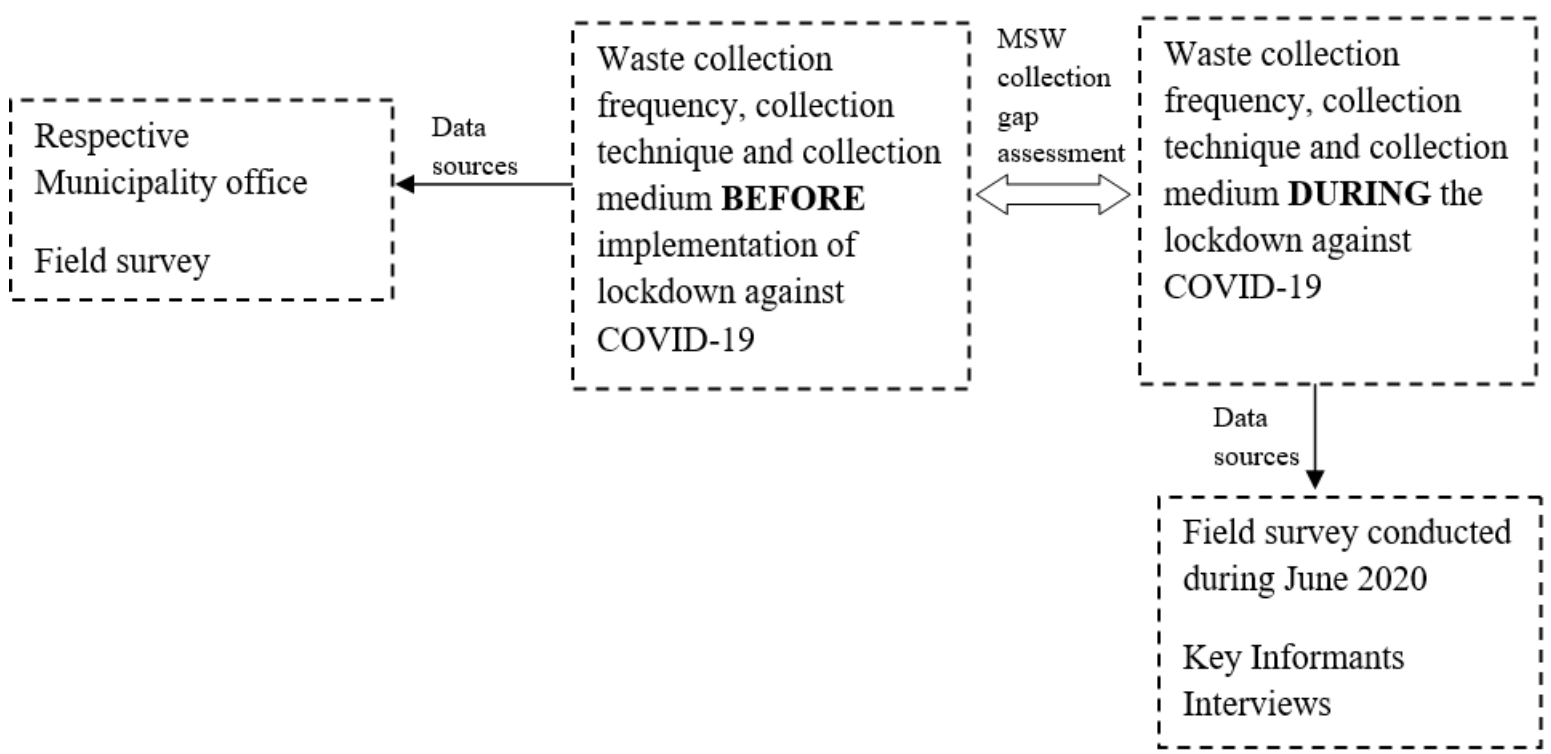

Figure 2 Method used for gap assessment of MSW collection before and after implementing lockdown against COVID-19 in Nepal.

\section{Results and Discussion}

\section{Status of SW Collection}

\section{A Case of Kathmandu Valley}

Figure 3 shows the status of the Solid Waste Collection before and during the lockdown. The results show that Kathmandu Valley (Kathmandu Metropolitan City, Lalitpur Sub-Metropolitan City and the Bhaktapur municipality) experiences a SW collection gap of around 880 tons/day (Fig 3). This shows a remarkable reduction of SW collection in the valley. There are around 25 private companies assigned in the valley for waste management which currently charges each household NRs 250 to NRs 400 per month for waste management. During the KII, the officials of Kathmandu Metropolitan City reported that many of the companies denied collecting solid waste as the workers were at heightened risk of contracting COVID-19 from objects that the infected personnel has discarded. The Solid Waste Management Association of Nepal (SWMAN) claimed that they provided service in all areas, but the collection frequency changed due to the changes in the mobilization of solid waste workers. Besides, the collection services were interrupted, causing the pre-collected waste to be on hold at Teku Dumping Site as the Sisdol Landfill site was halted for a week due to the protest by locals claiming that the 
coronavirus would spread in their locality from the wastes collected from different communities of the Kathmandu Valley. One of the private companies involved in MSWM in Kathmandu Valley reported that inadequate supplies of personal protective equipment and other safety gears are the reasons to disturb the resuming of waste collection and handling. It was reported that the attitude of some local people towards solid waste workers further added challenge as they were accused as modes of retransmission of virus to community.

\section{The Cases of Pokhara and Bharatpur Metropolis}

It was found that, in Pokhara Metropolitan City, solid waste collection in wards $6,11,12,13$ and 14 is monitored by a non-governmental company, while another private agency settles waste collection in wards $1,2,3,5,7,8,9,10,14,15$, and 17 and remaining wards by Pokhara Metropolitan City office. Officials of the company reported that the collection frequency has reduced to once a week. Overall, the collection rate has dropped by 66 tons/day (Fig 3), as the waste generated from the tourist area and educational sites have reduced. Similarly, in Bharatpur Metropolitan City, the SW collection decreased more than half times than usual during the lockdown (Fig 3).

\section{The Cases of Four Sub-metropolitan Cities}

The results show that Butwal Sub-Metropolitan city experienced a collection gap of about 5 tons/day. The environmental officer of Butwal Sub-Metropolitan city claimed that the SW collection services had been unaltered during the lockdown and the figures showing the collection gap is due to reduced SW generation at the schools, colleges, and commercial centres. The Sub-Metro adds that the health and safety of solid waste workers in their area have been its matter of primary concern, and thus it has been providing the workers with safety gears and equipment in order to ensure continual services.

Itahari Sub-Metropolitan experienced a collection gap of 23.58 tons/day as the collection frequency declined abruptly because of the risk of virus transmission to the workers and local people. The environmental officer reported a net increase in solid waste from household and slaughterhouses, whereas decreased from schools and industries. In the first 14 days of lockdown, the waste management facility was utterly halted. Sub-Metropolitan has experienced an increase in incineration and riverside dumping, which was recognized to be possible sites for various air-borne diseases during the lockdown. The waste management facility covers 22 wards of the sub-metropolitan.

According to a governmental official of Hetauda SubMetropolitan city, the waste collection in all wards is managed by the sub-metropolitan city itself. In wards $1,2,4$, 5 , and 10, collection frequency is as usual before and after lockdown, and in the rest of the wards, collection frequency has reduced. Tentatively the waste collection in Hetauda Submetropolitan City has reduced by $25 \%$ during lockdown (Fig 3).

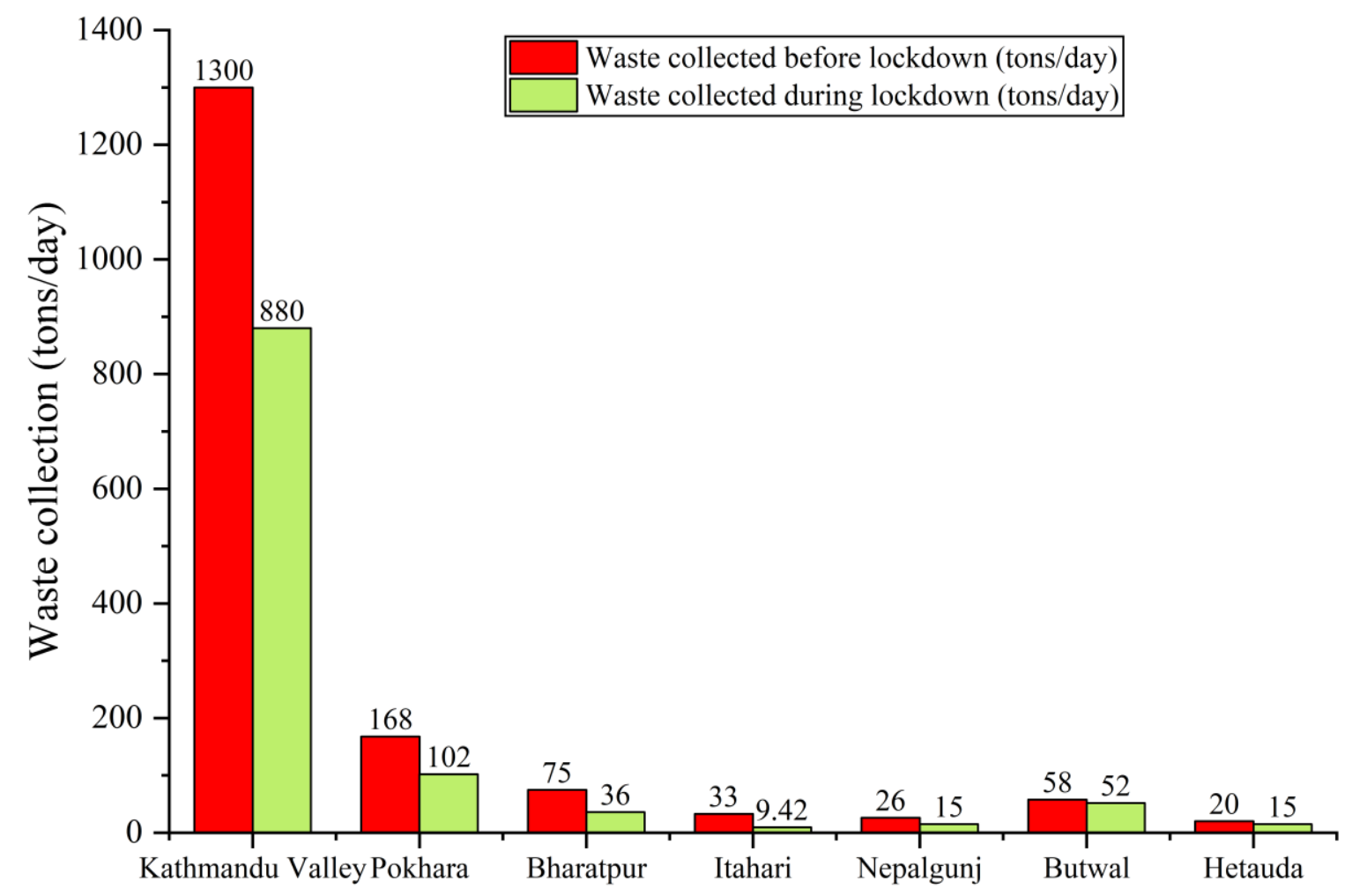

Figure 3 SW collection status in selected cities before and during the lockdown. 
In Nepalgunj Submetropolitan city, the waste collection rate has decreased, creating a waste collection gap of around 11 tons of waste per day. According to the official statement, fear of COVID-19 among the staff and officials is the main reason behind the lag in waste collection. However, they claimed that they were maintaining the collection frequency, which did not match with the response from respondents (Fig. 4).

\section{Frequency of SW Collection Before and During Lockdown}

In totality, Figure 4 provides an overview of the difference observed in the frequency of solid waste collection before and during the lockdown. The results show that the respondents report a sharp decrease in the usual frequency of SW collection during the lockdown. It is seen that $51.54 \%$ of the total respondents reported twice a week collection service before lockdown. Similarly, $32.36 \%$ reported daily collection service, followed by $11.81 \%$ reporting once a week collection service and 1.13\% reporting alternate day collection service in their household premises before lockdown. The results during lockdown reveal $54 \%$ of respondents reporting once a week collection service, $24.2 \%$ reporting twice a week collection service, $10.7 \%$ reporting twice a week collection service, followed by $7.9 \%$ reporting daily collection service. In spite of municipal officials claiming similar waste collection coverage rates in all areas of their service operations, it can be seen that the average collection frequency of twice a week before lockdown has been dropped down to around once a week collection practices during the lockdown. This leads to the accumulation of SW between the collection periods exacerbating the adverse health and environmental impacts (Alam \& Ahmade, 2013). Leachate dripping from the accumulated garbage also becomes common. The spread of unpleasant odour, insects and rodents around the accumulated wastes can be a major factor in the spread of insect-borne gastrointestinal and parasitic diseases (such as gastroenteritis, dengue and malaria) in crowded communities (Alam \& Ahmade, 2013; Maton et al., 2016)It has been found that accumulation of solid waste often in excess of seven days supports the breeding of Aedes aegypti and increases the transmission of dengue (Abeyewickreme et al., 2012). Thus, the gaps induced in SW collection frequency due to the ongoing pandemic could induce other health problems in different cities of Nepal, further inducing worse situations of national health.

The survey reports $93.7 \%$ of respondents claiming protest by workers due to fear of virus as the reason behind the halt in collection services experienced during the lockdown. While most of the people are forced indoors due to the lockdown, the sanitation workers continue to go from road to road to alley collecting garbage and sweeping the streets, and they could come in contact with the objects that could host the coronavirus. Due to the unavailability of proper protective gears, the garbage collectors are at risk of exposure to COVID-19. A large number of formal and informal SW workers in Kathmandu had returned to their villages with the announcement of a nationwide lockdown.
Even after the reopening of waste collection centres, there was strong hesitation among remaining workers to resume work. As a result, the capital city saw a sudden rise in solid waste mismanagement with piles of waste from households getting dumped on the sideways and the scenarios were similar at other cities as well. The World Health Organization's (WHO) COVID-19 interim guidance report suggests, "Best practices for protecting the health of workers at waste and sanitation treatment facilities should be followed, workers should wear appropriate Personal Protective Equipment (PPE), which includes protective outerwear, gloves, boots, goggles or a facial shield, and a mask and they should perform hand hygiene frequently" (WHO, 2020; UNICEF, 2020). Despite this guidance, the workers were not following the measures, and concerned authorities have not been promising to help workers due to budget and shortage of equipment supplies.

\section{Types of Vehicles Used for SW Collection}

Table 1 gives an overview of the types of vehicles operated for SW collection for the nine municipalities studied. The wastes collected by these vehicles are disposed of at respective transfer stations before the final disposal at the landfill sites. Out of the nine municipalities chosen for study, it was found that Butwal and Hetauda had composting plants at the final waste disposal sites. However, Butwal Sub-Metro reports experiencing halts in the operation of the composting plant due to technical issues. From the figures, it could be seen that Kathmandu Metropolitan City, Lalitpur Sub-Metropolitan City and Pokhara Metropolitan City show the highest use of dump trucks for SW collection. In contrast, the remaining six cities, namely Bhaktapur Municipality, Bharatpur Metropolitan city, Hetauda Sub-Metropolitan city, Butwal Sub-Metropolitan City and Nepalgunj Sub-Metropolitan city show maximum usage of tractors for SW collection. The circulated usage of dump trucks and tippers could be seen more in metropolitan and sub-metropolitan cities with higher population density and improved road facilities, followed by the cluster of tractors, mini-trucks, rickshaws and carts usage in semi-urban areas comprising of relatively smaller road networks and lower population density. The variation of figures could be noticed in Bhaktapur municipality reporting similar ratios of dump trucks $(39.6 \%)$ and tractors $(37.4 \%)$ usage followed by trippers $(22 \%)$ for SW collection. This is because, along with urban areas, the municipality also consists of some semi-urban and rural area networks with limited road access, which fosters the use of tractors.

\section{SW Management Methods Adopted by Households}

Household waste management is critical when home isolation is prescribed for COVID-19 patients (Yousefi et al., 2021). When an infected or suspected individual is treated at home, the household waste requires unusual attention and proper management (Di Maria et al. 2020; Yousefi et al., 2021). These domestic wastes from infected or suspected household require separate management than other household wastes and this change in household waste 
management is a necessity during the pandemic (Klemeš et al., 2020).

Figure 5 portrays the overall picture of the alternative solid waste management methods adopted by households during the lockdown period. The results reveal that $52.4 \%$ of the respondents managed SW by storing the waste with proper management, $18.9 \%$ practiced burning of wastes, $25.7 \%$ adopted land composting and $1.2 \%$ throwing wastes in streets. With half of the respondents claiming to store waste with proper management, the practice somehow has a positive side as it indirectly induces the reduction of wastes at the household level. However, the accumulated wastes can be hazardous and can contaminate the surrounding if

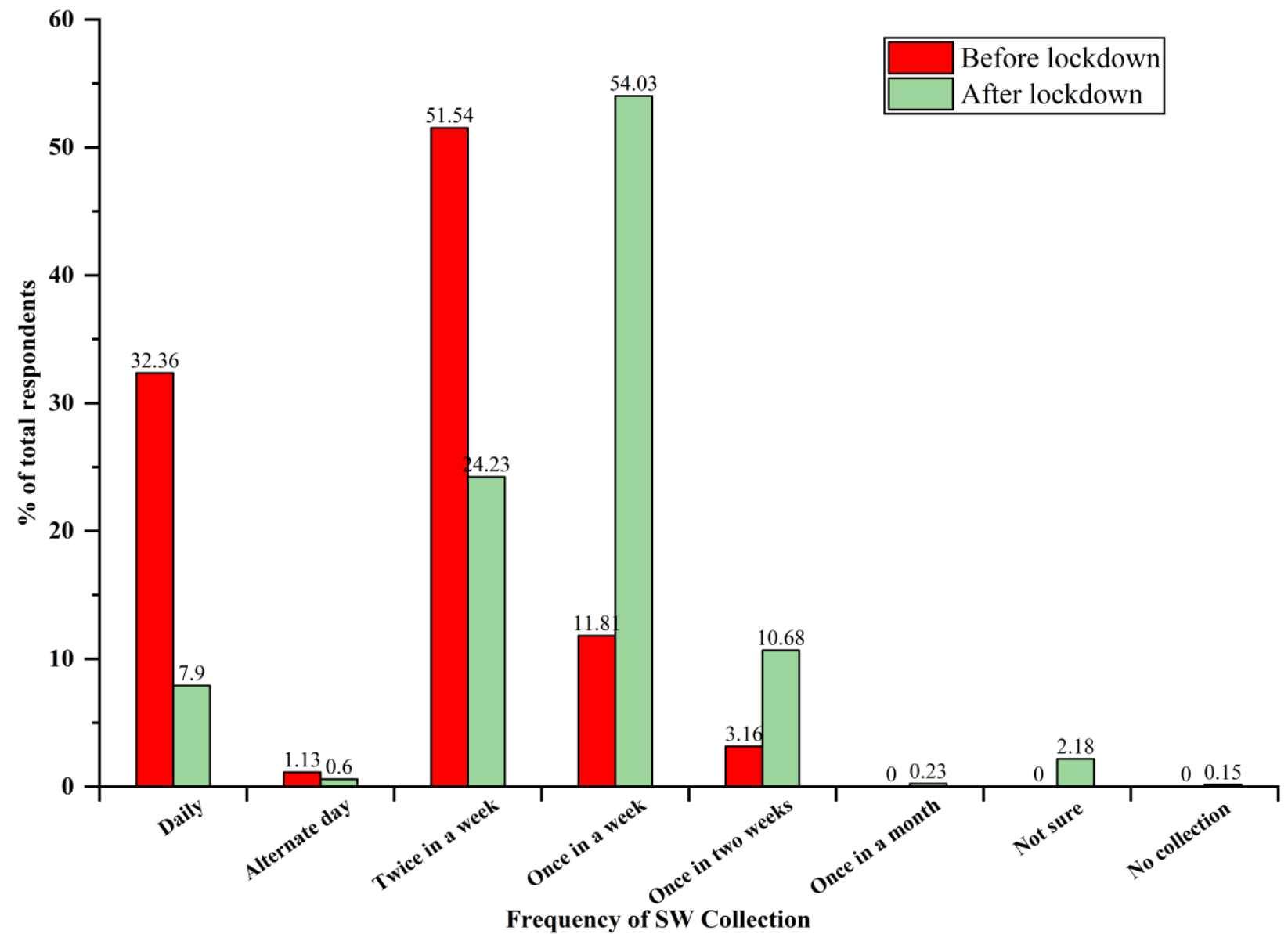

Figure 4 Respondents response to the frequency of SW collection before and during the lockdown.

Table 1 Types of vehicles used in SW Collection in 9 selected cities. Percentages are based on responses.

\begin{tabular}{rrrrrrr}
\hline Cities & \multicolumn{7}{c}{ Type of vehicles used for the SW Collection } \\
\cline { 2 - 7 } & Dump Trucks & Mini Trucks & Tractors & Tipper & Rickshaws and carts & Van and Others \\
\hline Kathmandu & $60.2 \%$ & $4.5 \%$ & $17.6 \%$ & $6.3 \%$ & $10.9 \%$ & $0.5 \%$ \\
Lalitpur & $60.6 \%$ & $6.9 \%$ & $8.8 \%$ & $5.0 \%$ & $18.8 \%$ & $0.0 \%$ \\
Bhaktapur & $39.6 \%$ & $0.0 \%$ & $37.4 \%$ & $22.0 \%$ & $0.0 \%$ & $0.0 \%$ \\
Bharatpur & $13.4 \%$ & $0.0 \%$ & $55.8 \%$ & $30.8 \%$ & $9.6 \%$ & $0.0 \%$ \\
Hetauda & $20.0 \%$ & $3.2 \%$ & $58.4 \%$ & $8.8 \%$ & $0.9 \%$ & $0.0 \%$ \\
Itahari & $2.8 \%$ & $0.0 \%$ & $96.3 \%$ & $0.0 \%$ & $0.0 \%$ & $0.0 \%$ \\
Pokhara & $62.3 \%$ & $0.0 \%$ & $1.8 \%$ & $36.0 \%$ & $4.6 \%$ & $0.0 \%$ \\
Butwal & $3.3 \%$ & $0.0 \%$ & $84.1 \%$ & $7.9 \%$ & $0.0 \%$ & $0.0 \%$ \\
Nepaljung & $17.1 \%$ & $0.0 \%$ & $62.8 \%$ & $0.8 \%$ & $18.6 \%$ & $0.1 \%$ \\
\hline$\%$ of Total & $35.1 \%$ & $1.8 \%$ & $41.3 \%$ & $14.5 \%$ & & $0.1 \%$ \\
\hline
\end{tabular}


not appropriately handled. Alarmingly, none of the household reported to have separately manage waste from infected or suspected individual at home. Organic domestic waste poses a serious threat since they ferment and create conditions favourable to the survival and growth of microbial pathogens like Enterobacteriaceae, Shigella, Chlamydia trachomatis.

The odour and leachate generation from accumulated wastes make favourable conditions for insects, flies and rodents to breed around them, inducing a number of bacterial diseases like salmonellosis, shigellosis, staphylococcal capable of food poisoning along with viral diseases (Alam \& Ahmade, 2013; Lembke \& Kniseley, 1985). As a result, the prolonged storage of SW at the household level does not

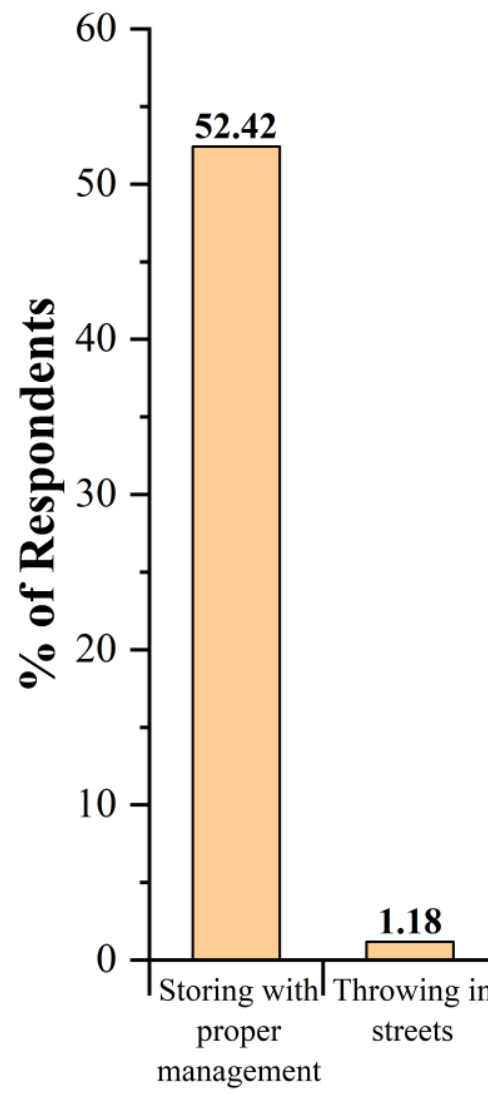

seem to be an effective method. It is worrisome to see from the results that $18.9 \%$ practice burning wastes without proper management and safety requirements. The main justification for why many areas practice waste burning as one of the SW management methods is volume reduction. However, studies reveal that open burning release toxic like nitrogen oxides, sulphur dioxide, volatile organic chemicals (VOCs) and carcinogenic gases like polycyclic organic matter (POMs), benzo(a)pyrene (BAP) and polyaromatic hydrocarbons (PAHs); mainly if the waste contains plastic materials (Tomatis, 2012; Zhang, 1997). People practising open burning are found to be at greater risks of chronic respiratory diseases, including cancers resulting from exposures to dust and hazardous compounds (Kampa \& Castanas, 2008).
25.7

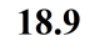

Management method addopted by Households

Figure 5 SW management method adopted by HHs during lockdown against COVID-19.

The released gases also impose long term effects on the environment and groundwater. It is seen that $25.7 \%$ of the respondents reported land composting as their alternatives to SW management at the household level during the lockdown, which is one of the best methods of maintaining and enhancing soil fertility (Gautam et al., 2010; Pokhrel \& Viraraghavan, 2005). The transformation of organic waste products into humus-rich soil teeming with beneficial microbes certainly carries a great value, but the alternative does not seem feasible to the majority of housings in the chosen cities of Nepal, where ample land is being changed into private and commercialized living quarters in the verge of rapid urbanization (Pokhrel and Viraraghavan, 2005). In most of the cities, the households are confined in clusters with one other holding a concentrated population and thus, the amount required for land composting is not available in most cases. It was noticed that $1.2 \%$ of the respondents reported throwing wastes in streets which induces outbreaks of other diseases. Moreover, leachate from such random dumps contaminates groundwater in the long run.

\section{Conclusion}

This study performed the 1329 household questionnaire survey and key informant interviews in seven cities of Nepal 
to analyse the status of solid waste (SW) collection and management before and during the nationwide lockdown against COVID-19. The results show that SW collection dropped approximatively by 570 tons/day in seven selected cities of Nepal during the lockdown. Kathmandu Valley experienced a maximum difference in SW collection before and during the lockdown out of seven cities. The major reduction in the SW collection during lockdown is primarily due to reduced commercial wastes and collection frequency. The respondents report a sharp decrease in the usual frequency of SW collection by municipalities during the lockdown. It was found that the usual frequency of waste collection reduced to once or twice a week. This led to pileup SW inside the house and streets, inducing other health problems. Various vehicles, such as dump trucks, mini trucks, tractors, tippers, rickshaws and carts, as usual, were used as the medium to collect solid waste during the lockdown. It is worthy to note that the usage of dump trucks and tippers was seen more in metropolitan and submetropolitan cities with higher population density and improved road facilities, followed by the usages of tractors, mini-trucks, rickshaws and carts in semi-urban areas with relatively smaller road networks and lower population density. Since the SW collection frequency reduced during the lockdown, households adopted different alternative methods to manage the SW. More than $50 \%$ the total surveyed households managed the SW by storing it with proper management to provide the waste on the day of municipal waste collection. About $26 \%$ and $19 \%$ of households adopted land composting and open burning to manage waste during the lockdown. Based the findings of the study, it can be concluded that the practice of municipal vehicles collecting wastes from door to door, roads, and alleys has made the public less concerned about managing the organic wastes at the household level.

It has been found that despite being aware of modes of transmission and safety measures, solid waste workers are at high risk of exposure to the virus due to inadequate and non-uniform distribution of safety gears. This could further lead to worse contexts, with solid waste workers being the modes for retransmission of virus to the community. Along with other essential sectors, the government should prioritize the safety and insurance of solid waste workers since the continual priority to the health sector alone cannot ultimately reduce the COVID-19 vulnerability. The study concludes that the uninterrupted SW collection service during the pandemic is utmost and requires sound understanding, participation and coordination of activities among waste management authorities, solid waste workers and the public.

Acknowledgements: The authors would like to thank the several volunteering surveyors who conducted the households survey of this study.

Author Contributions: Bikash Adhikari (B.A.) and Saroj Koirala (S.K.) conceived and designed the research. Nitesh Koirala (N.K².), B.A. collected data, B.A., S.K., Nitesh Khadka (N.K ${ }^{1}$.) and N.K ${ }^{2}$ processed and analysed the data.
All authors contributed to discussing the results and writing the paper. All authors have read and agreed to the final version of the article.

Conflict of Interest: The authors declare no conflict of interest.

\section{References}

Abeyewickreme, W., Wickremasinghe, A.R., Karunatilake, K., Sommerfeld, J., \& Axel, K. (2012). Community mobilization and household level waste management for dengue vector control in Gampaha district of Sri Lanka; an intervention study. Pathogens and Global Health, 106(8), 479-487. doi 10.1179/2047773212 Y.0000000060.

Alam, P., \& Ahmade, K. (2013) Impact of solid waste on health and the environment. International Journal of Sustainable Development and Green Economics, 2, 165-168.

CBS. (2012). National population and housing census 2011. National Report, Central Bureau of Statistics, Kathmandu, Nepal.

D’Amato, A., Mancinelli, S., \& Zoli, M. (2016). Complementarity vs substitutability in waste management behaviors. Ecological Economics, 123, 84-94. doi 10.1016/j. ecolecon.2015.12.005.

De Feo, G., Ferrara, C., Iannone, V., \& Parente, P. (2019). Improving the efficacy of municipal solid waste collection with a communicative approach based on easily understandable indicators. Science of the Total Environment, 651, 2380-2390. doi 10.1016/j.scitotenv. 2018.10.161.

Di Maria, F., Beccaloni, E., Bonadonna, L., Cini, C., Confalonieri, E., La Rosa, G., Milana, M.R., Testai, E., \& Scaini, F. (2020). Minimization of spreading of SARS$\mathrm{CoV}-2$ via household waste produced by subjects affected by COVID-19 or in quarantine. Science of the Total Environment, 743,140803.

Ferronato, N., \& Torretta, V. (2019). Waste mismanagement in developing countries: A review of global issues. International Journal of Environmental Research and Public Health, 16(6), 1060. doi 10.3390/ijerph 16061060.

Gautam, S., Bundela, P., Pandey, A., Awasthi, M. \& Sarsaiya, S. (2010). Composting of municipal solid waste of Jabalpur city. Global Journal of Environmental Research, 4, 4346.

Guerrero, L.A., Maas, G., \& Hogland, W. (2013). Solid waste management challenges for cities in developing countries. Waste Management, 33(1), 220-232. doi 10.1016/j.wasman.2012.09.008.

Gupta, N., Yadav, K.K., \& Kumar, V. (2015). A review on current status of municipal solid waste management in India. Journal of Environmental Sciences, 37, 206-217. doi 10.1016/j.jes.2015.01.034.

Kampa, M., \& Castanas, E. (2008) Human health effects of air pollution. Environmental Pollution, 151, 362-367. doi 10.1016/j.envpol.2007.06.012.

Klemeš, J.J., Van Fan, Y., Tan, R.R., \& Jiang, P. (2020). Minimising the present and future plastic waste, energy and environmental footprints related to COVID-19. Renewable and Sustainable Energy Reviews, 127, 109883.

Laurent, A., Bakas, I., Clavreul, J., Bernstad, A., Niero, M., Gentil, E., Hauschild, M.Z., \& Christensen, T.H. (2014). 
Nep J Environ Sci (2021), 9(1), 11-19

https://doi.org/10.3126/njes.v9i1.36991

Review of LCA studies of solid waste management systems - Part I: Lessons learned and perspectives. Waste Management, 34(3), 573-588. doi 10.1016/ j.wasman.2013 .10 .045 .

Lembke, L.L., \& Kniseley, R.N. (1985) Airborne microorganisms in a municipal solid waste recovery system. Canadian Journal of Microbiology, 31, 198-205. doi 10.1139/m85-038.

Maton, S.M., Dabi, D.D., Dodo, J.D., \& Nesla, R.A. (2016) Environmental hazards of continued solid waste generation and poor disposal in municipal areas of Nigeria. Journal of Geography, Environment and Earth Science International, 6(3), 1-10.

Minelgaite, A., \& Liobikiené, G. (2019). Waste problem in European Union and its influence on waste management behaviours. Science of the Total Environment, 667, 86-93. doi 10.1016/j.scitotenv.2019.02.313.

Minghua, Z., Xiumin, F., Rovetta, A., Qichang, H., Vicentini, F., Bingkai, L., Giusti, A., \& Yi, L. (2009). Municipal solid waste management in Pudong New Area, China. Waste Management, 29(3), 1227-1233. doi 10.1016/j .wasman.2008.07.016

Mol, M.P.G., \& Caldas, S. (2020). Can the human coronavirus epidemic also spread through solid waste? Waste Management and Research, 38(5), 485-486. doi 10.1177 /0734242X20918312.

Pokhrel, D., \& Viraraghavan, T. (2005) Municipal solid waste management in Nepal: practices and challenges. Waste Management, 25, 555-562. doi 10.1016/ j.wasman.20 05.01.020

Pun, S.B., Mandal, S., Bhandari, L., Jha, S., Rajbhandari, S., Mishra, A.K., \& Shah, R. (2020) Understanding COVID19 in Nepal. Journal of Nepal Health Research Council, 18, 126-127. doi 10.33314/jnhrc.v18i1.2629.

Saxena, S., Srivastava, R.K., \& Samaddar, A.B. (2010). Sustainable waste management issues in India. The IUP Journal of Soil and Water Sciences, 3(1), 72-90.

Sharma, S., Hamal, K., Khadka, N., \& Joshi, B.B. (2020). Dominant pattern of year-to-year variability of summer precipitation in Nepal during 19872015. Theoretical and Applied Climatology, 142, 1071-1084. doi 10.1007/s00704-020-03359-1.
Stoeva, K., \& Alriksson, S. (2017). Influence of recycling programme on waster separation behaviour Waste Management, 68, 732-741. doi 10.1016/j.wasman.2017.06.0 05.

Tomatis, L. (2012). Indoor and outdoor air pollution and human cancer, Springer Science \& Business Media. VII, 162, Springer-Verlag Berlin Heidelberg doi: 10.1007/9783-642-78197-1.

WHO. (2020). Water, sanitation, hygiene and waste management for the COVID-19 virus. World Health Organisation, March, 1-9.

World Bank. (2012). A global review of solid waste management - review, global management, solid waste. World Bank Urban Development Series Knowledge Papers, January 2012, 1-116.

UNICEF. (2020). Water, sanitation, hygiene, and waste management for the COVID-19 virus: interim guidance. World Health Organization. Retrieved 19 March 2020 from https://apps.who.int/iris/handle/10665/331499.

Wu, J.T., Leung, K., \& Leung, G.M. (2020). Nowcasting and forecasting the potential domestic and international spread of the 2019-nCoV outbreak originating in Wuhan, China: a modelling study. The Lancet, 395, 689-697. doi 10.1016/S0140-6736(20)30302-0.

Yousefi, M., Oskoei, V., Jafari, A.J., Farzadkia, M., Firooz, M.H., Abdollahinejad, B., \& Torkashvand, J. (2021). Municipal solid waste management during COVID-19 pandemic: effects and repercussions. Environmental Science and Pollution Research, 28, 32200-32209.

Zhang, X. (1997). Emissions from waste combustion. An application of statistical experimental design in a laboratory-scale boiler and an investigation from largescale incineration plants. Sweden. Retrieved 5 January 2020 from https://doi.org/10.1007/s11356-021-14214-9.

Zhu, D., Asnani, P.U., Zurbrügg, C., Anapolsky, S., \& Mani, S. (2008). Improving municipal solid waste management in India: A sourcebook for policy makers. The World Bank, Washington DC. doi 10.1596/978-0-8213-7361-3. 